\title{
NEST AND NEST CHARACTERISTICS OF COMMON KINGFISHER (ALCEDO ATTHIS) AND WHITE-THROATED KINGFISHER (HALCYON SMYRNENSIS) IN BANGLADESH
}

\author{
Habibon Naher*1 and Noor Jahan Sarker \\ Department of Zoology, University of Dhaka, Dhaka 1000, Bangladesh
}

\begin{abstract}
This study was on nest and its site, measurement and building time of Common Kingfisher (Alcedo atthis) and White-throated Kingfisher (Halcyon smyrnensis) in Bangladesh. After pair formation, both species chose nearly $90^{\circ}$ sloppy sandy-loam areas for nesting. The nests were tunnel-like, the length of which were 31 to $48 \mathrm{~cm}$ (median $36.5 \mathrm{~cm}, \mathrm{n}=8$ ) for Common Kingfisher and 44 to $86 \mathrm{~cm}$ (median $59.25 \mathrm{~cm}, \mathrm{n}=10$ ) for White-throated Kingfisher. The horizontal diameter of the outer opening of the hole of White-throated Kingfisher was almost double $(6.5$ to $14 \mathrm{~cm}$, median $9.5 \mathrm{~cm}, \mathrm{n}=10$ ) than Common Kingfisher (3.8 to 5 $\mathrm{cm}$, median $4.25 \mathrm{~cm}, \mathrm{n}=8$ ), whereas the vertical diameter was almost same (Common: 7.7 to $10 \mathrm{~cm}$, median $4.25 \mathrm{~cm}, \mathrm{n}=8$; and White-throated: 7.5 to $12 \mathrm{~cm}$, median $10.5 \mathrm{~cm}, \mathrm{n}=10$ ). The average horizontal and vertical diameters of ovalshaped egg chamber of Common Kingfisher were, 11 to $15 \mathrm{~cm}$, respectively (median $12.7 \mathrm{~cm}, \mathrm{n}=8$ ) and 11 to $13 \mathrm{~cm}$ (median $11.6 \mathrm{~cm}, \mathrm{n}=8$ ) and Whitethroated Kingfisher 11 to $21 \mathrm{~cm}$ (median $17 \mathrm{~cm}, \mathrm{n}=10$ ) and 10 to $16 \mathrm{~cm}$ (median $12 \mathrm{~cm}, \mathrm{n}=10)$. Both species reused old nests through cleaning $(37.5 \%$ in Common Kingfisher and 50\% in White-throated Kingfisher) and the nest building periods were 12 to 20 days $(16.1 \pm 2.5$ days, $\mathrm{n}=8)$ and 8 to 18 days $(13.2 \pm 3.5$ days, $\mathrm{n}=10$ ), respectively.
\end{abstract}

Key words: Common kingfisher, white-throated kingfisher, nest, nesting

\section{INTRODUCTION}

The kingfishers (Coraciiformes: Families Alcedinidae, Dalcelonidae and Cerylidae) are very popular for their bright colourful plumage and long daggerlike bill. They are the birds of the waterside, live frequent beside lakes, ponds, canals or dykes and streams (Wikipedia 2015a). Among the 12 species of kingfishers found in Bangladesh (IUCN 2000, Siddiqui et al. 2008) the common kingfisher and white-breasted or white-throated kingfisher are very common resident birds.

Birds build their nests for the safety of their eggs and young (Ali 1979). Kingfishers do not need any special nest material but chose a very specific place where to dig the nest hole, mostly loamy banks along streams and soft enough to be excavated but secure enough to avoid collapse caused rain by water and the water stream below or by larger amount of precipitation which may occur

"Corresponding author: habibonnaher@yahoo.com, ${ }^{1}$ Department of Zoology, Jagannath University, Dhaka-1100, Bangladesh

(C) 2016 Zoological Society of Bangladesh DOI: 10.3329/bjz.v44i1.30180 
during the breeding period (Heneberg 2004). Nesting in holes in sandy or loamy embankments is not uncommon among birds. It is considered as providing protection from changes in weather (Hoogland and Sherman 1976) and from predators (Lack 1968). Some information on nest and nesting ecology of whitethroated kingfisher is available throughout the world (Ali et al. 2010, Balasubramanian 1992, Madhuramozhi 2008, Morgan and Glue 1977, Palkar et al. 2009) but information on common kingfisher is scanty (Heneberg 2008, Morgan and Glue 1977). In Bangladesh, no published paper is available on the nest and nesting characteristics of common and white-throated kingfishers. Thus an attempt was taken to study the nest and nest characteristics of common kingfisher and white-throated kingfisher in Bangladesh.

The study was carried out in Dhaka and Chittagong, Bangladesh from September 2008 to August 2011. In Dhaka, Bangladesh National Museum Campus (BNMC) in Shahabag, Nikunja-1 in Uttara, different villages of Savar (Madhabchala, Islamnagar, Kashipur, Boro-Walia, Battali, Sandeep, Bowalia Para and Sinduria) and in Chittagong, Chittagong University Campus (CUC) were selected. The nests of common kingfisher were studied only in Dhaka and the nests of white-throated kingfisher were studied in Dhaka and CUC.

\section{MATERIAL AND METHODS}

Nest building activities of the kingfishers were observed with a pair of binoculars (Bushnell $20 \times 280 \mathrm{~mm}$ with multicoated lens) and the duration was recorded with an electronic stopwatch. A tape scale (graduated 1 to $150 \mathrm{~cm}$ ) was used to take different measurements of nest hole. Nest building behaviour was observed from 07:00 to 19:00 hrs and at each three alternative days, each day was divided into four time blocks: early morning (07:00 to 10:00), late morning (10:01 to $13: 00)$, midday (13:01 to $16: 00)$ and afternoon (16:01 to $19: 00)$. Data were collected by using the focal animal sampling methods of Altmann (1974). A total of 300 hours and 900 scans were spent to observe the nest building behaviour for each species. In each one hour, there were three 15 minute continuous monitoring periods followed by 5 -minute intervals while only one bird was monitored.

\section{RESULTS AND DISCUSSION}

After the pair formation (May-June for common kingfisher and March-April for white-throated kingfisher), both partners of both kingfishers were busy in searching and selecting a suitable nesting site. Both species chose sandy-loam area where they could dig holes comfortably. The observed nesting areas of both species were always nearly $90^{\circ}$ sloppy (Table 1), newly cut down for any purpose

or eroded hills/heaps. The common kingfisher always built their nests at the 
bank of lake, pond, river or near the paddy field and ditch but preferred pond bank while the white-throated kingfisher built their nests near or far from water bodies and preferred steep hills (Fig. 1). The present study supports the findings of Whistler (1986). The nesting sites of common kingfisher were sandy or loamy banks of different types of water bodies as observed by others (Campos et al. 2000, Flegg 1984, Heneberg 2004, Iribarren and Nevado 1982, Morgan and Glue 1977, Peris and Rodriguez 1996, 1997, Raven 1986). But some other authors differed and stated that all the nests were located along the sandy riverbanks (Ali et al. 2010, Morgan and Glue 1977, Brooks and Davis 1987, Peris and Rodriguez 1997, Heneberg 2004, Madhuramozhi 2008, Avian web 2015, Wikipedia 2015a,b, Jerdon 1982, Whistler 1986). It was also true that sometimes nests are built in some unknown or less common areas like termitarium, rock, crevice, in a haystack, under a projecting stone on the bank of a nullah, in decaying trees, the shafts of unbricked walls (Wikipedia 2015a,b, Avian web 2015, Jerdon 1982, Whistler 1986). In India, Ali and Ripley (1987) reported that the nests of both species are bored in the steep bank of a dry 'nullah' (canals) or roadside cutting or in the side of a dry ditch. The birds prefer to nests in sandy soil because it provides a number of advantages such areas have lower soil pressure, density and moisture than more clay rich soils (Ali et al. 2010). It also provides faster and easier excavation of nest cavities (op. cit.). The high porosity of sandy soils would also have better ventilation, which is important to diffuse gases to maintain a tolerable level of $\mathrm{O}_{2}$ and $\mathrm{CO}_{2}$ in the nest cavities (White et al. 1978). Soil particle size could also affect the structure of the nest tunnels of the white-throated kingfisher (Wikipedia 2015 a,b).

The nesting sites of the white-throated kingfisher were not always situated near water bodies (50\% near water body). The distance between nest hole and water source was 112 to $184 \mathrm{~cm}$ (median $155.6 \pm 24.5 \mathrm{~cm}, \mathrm{n}=8$ ) for the common kingfisher (CK) and 24 to $1018 \mathrm{~cm}$ (median $404.6 \pm 352.4 \mathrm{~cm}, \mathrm{n}=10$ ) for the white-throated kingfisher (WTK) while the nests were built near water bodies (Table 1). The distance of nest site from water source varies significantly varied (CK: $\chi^{2}=125.5, \mathrm{df}=7, \mathrm{p}<0.001$; WTK: $\chi^{2}=1227.45, \mathrm{df}=9, \mathrm{p}>0.001$ ).

The nesting sites of both species were in abandoned, isolated and near or away from human habitations. When the nests were built near human habitation, they selected such sites where there was less or no human movement at all. However, an appropriate nesting site must offer food, shelter from predators and protection from unfavourable weather conditions (Lack 1968, Hoogland and Sherman 1976, Li and Martin 1991, Martin and Roper 1988). Heneberg (2004) reported that the nest sites of the common kingfisher do not display a strong selection dependence on the vegetation cover close around the nesting place. 
When a pair select the nesting site, they start nest building immediately and both partners take part in nest construction alternatively. Ali and Ripley (1987) reported that both sexes share in nest excavating. Wikipedia $(2015 \mathrm{~b}, \mathrm{c})$ and Arkive (2015 a,b) also reported such behaviour for both species. During nest construction period, the mated pair of the common kingfisher is very vocal and displayed to each other continuously (Naturia 2014 a).

sCK $\square$ WTK

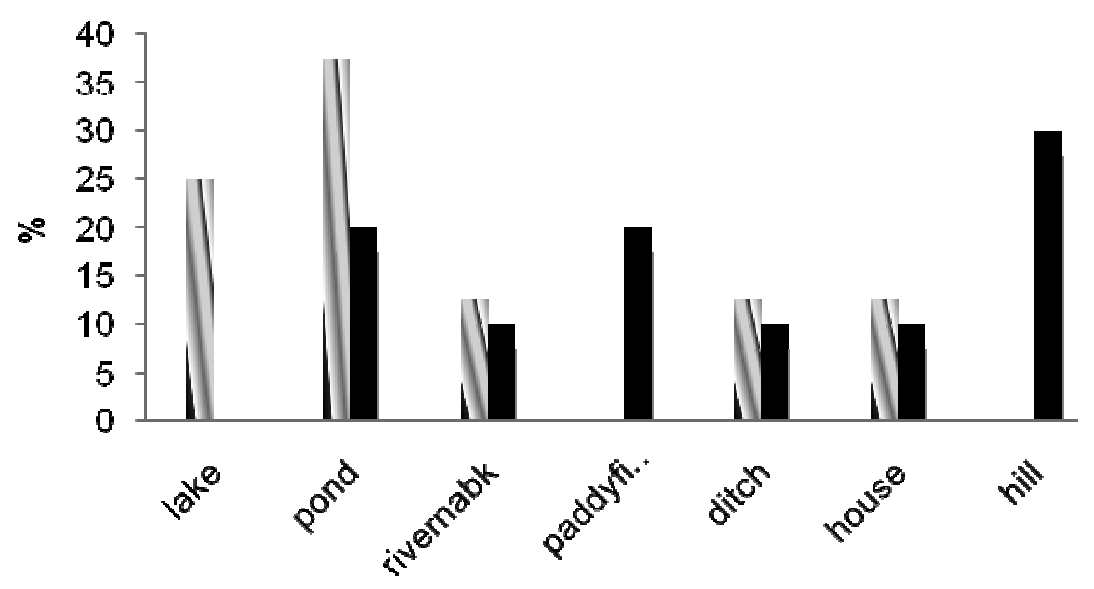

Fig. 1. Nest sites (CK denoted for Common and WTK for White-throated Kingfisher).

Before digging the nest hole, they sit on a tree branch or any substrate opposite of the nesting site. Then one of the partners flew to the nesting site, sit there and hit the soil with beak and flows back to its partner, and the other partner performs the same activities. In case of Common Kingfisher, each partner hits the soil 4 to 18 times (mean $11.9 \pm 4.8, \mathrm{n}=32$ ) and White-throated Kingfisher, it was 2 to 10 (mean $6 \pm 2.6 \mathrm{~min}, \mathrm{n}=30$ ). Then the pair of Common Kingfisher took rest for 1 to 25 minutes (mean $10.6 \pm 7.2 \mathrm{~min}, \mathrm{n}=32$ ) and White-throated Kingfisher took 3 to 30 minutes (mean $24.3 \pm 11.6 \mathrm{~min}, \mathrm{n}=10$ ), before starting the next session of digging hole. Within a minute, the common kingfisher did this activity for 2 to 4 times (median $3, \mathrm{n}=25$ ) and white-throated kingfisher 3 to 5 (mean $3.2 \pm 1.1, \mathrm{n}=10$ ) at the onset of nest building activities.

When one partner of white-throated kingfisher was digging the soil, the other partner uttered continuously "crack...crack...crack...crack" sound sitting on the opposite side of a tree branch or on electric wire and was flapping its wings repeatedly as if it inspired the other partner to dig hole. Such type of behaviour was not recorded for common kingfisher. Both species spent more time in nest building in the morning and afternoon (Fig. 2). 
Table 1. Distance of nest from water bodies

\begin{tabular}{|c|c|c|c|c|c|c|}
\hline \multirow[t]{2}{*}{$\begin{array}{c}\text { Nest } \\
\text { no. }\end{array}$} & \multicolumn{2}{|c|}{ Study site } & \multicolumn{2}{|c|}{ Location } & \multicolumn{2}{|c|}{$\begin{array}{c}\text { Distance of } \\
\text { water bodies }\end{array}$} \\
\hline & $\mathrm{CK}^{*}$ & $\mathrm{WTK}^{*}$ & $\mathrm{CK}^{*}$ & WTK* $^{*}$ & $\mathrm{CK}^{*}$ & WTK $^{*}$ \\
\hline 1 & Nikunjo & *BNMC & $\begin{array}{l}\text { At the bank of the lake, } \\
\text { the site selected by the } \\
\text { bird after removing a } \\
\text { heavy pillar. }\end{array}$ & $\begin{array}{l}\text { Only a single nest was } \\
\text { constructed at the eastern } \\
\text { side of the pond of the } \\
\text { Museum Campus. The } \\
\text { pond is situated on the } \\
\text { western side of the National } \\
\text { Museum, in between BNMC } \\
\text { office and Agrani Bank } \\
\text { building. }\end{array}$ & 158 & 341 \\
\hline 2 & Savar & CUC & $\begin{array}{l}\text { At the bank of a pond in } \\
\text { the village of Bara Walia. }\end{array}$ & On hill (called Katapahar) & 171 & Absent \\
\hline 3 & Nikunjo & Savar & $\begin{array}{l}\text { At the bank of the lake, } \\
\text { the bird chose this site } \\
\text { after cutting down for } \\
\text { bank construction. }\end{array}$ & $\begin{array}{l}\text { On cutting earth bank at } \\
\text { the back side of a house, } \\
\text { near a paddy field at the } \\
\text { village of Madhabchala }\end{array}$ & 163 & 200 \\
\hline 4 & Savar & Savar & $\begin{array}{l}\text { At the side a ditch where } \\
\text { seasonal vegetables were } \\
\text { cultivated in the village } \\
\text { of Bara Walia. }\end{array}$ & $\begin{array}{l}\text { On the cutting earth bank } \\
\text { near a paddy field in the } \\
\text { village Bara walia. }\end{array}$ & 180 & 244 \\
\hline 5 & Savar & Savar & $\begin{array}{l}\text { At the bank of a pond in } \\
\text { the village of Sinduria. }\end{array}$ & $\begin{array}{l}\text { on the } 90^{\circ} \text { cutting earth } \\
\text { bank at the back side of a } \\
\text { kitchen where wastages of } \\
\text { household were deposited } \\
\text { in Bara walia }\end{array}$ & $\begin{array}{l}112 \mathrm{~cm} \\
\text { below } \\
\text { from the } \\
\text { nest }\end{array}$ & Absent \\
\hline 6 & Savar & CUC & $\begin{array}{l}\text { At the back side of a } \\
\text { house in the village of } \\
\text { Bara Walia where the } \\
\text { soil was cut down for } \\
\text { household purposes in } \\
\text { front of which paddy } \\
\text { field was situated. }\end{array}$ & $\begin{array}{l}\text { On hill beside the central } \\
\text { mosque }\end{array}$ & 146 & Absent \\
\hline 7 & Savar & CUC & $\begin{array}{l}\text { at the bank of a pond in } \\
\text { the village of Kashipur. }\end{array}$ & On VC hill & 133 & Absent \\
\hline 8 & Savar & Savar & $\begin{array}{l}\text { At the bank of Sinduria } \\
\text { river in the village of } \\
\text { Sinduria. }\end{array}$ & $\begin{array}{l}\text { At the bank of Sinduria } \\
\text { river in the village of } \\
\text { Sinduria }\end{array}$ & 184 & 1018 \\
\hline 9 & - & Savar & - & $\begin{array}{l}\text { At the bank of a pond near } \\
\text { the back side of a house in } \\
\text { the village of Kashipur }\end{array}$ & & 296 \\
\hline 10 & - & Savar & - & $\begin{array}{l}\text { At the bank of a ditch } \\
\text { located at the back side of a } \\
\text { house in the village of } \\
\text { Islamnagar. }\end{array}$ & & $\begin{array}{l}124 \\
\mathrm{~cm} \\
\text { down }\end{array}$ \\
\hline
\end{tabular}

${ }^{*} \mathrm{CK}=$ Common kingfisher, WTK $=$ White-throated kingfisher, BNMC $=$ Bangladesh National Museum Campus. 
From the $10^{\text {th }}$ day of nest building, both partners of common kingfisher stayed together in the hole for long time but in case of white-throated kingfisher, one partner stayed in the hole after $13^{\text {th }}$ day for long period $(80 \%$ time/day) and observed that the bird came out only for feeding, bathing and preening. At day time it came for several times for feeding and at midday (13:00 -14:00 hrs) it took bath. The other partner of white-throated kingfisher stayed at the nearby tree branch or any substrate on the opposite side and guarding/supporting the nest building. Sometimes it went into the nest and stayed for some time (0.5 to $8.75 \mathrm{~min}$, median $4.6 \mathrm{~min}, \mathrm{n}=20$ ). The common kingfisher sometimes supplied food to the partner, who stayed inside the nest for long time but this behaviour was not recorded for white-throated kingfisher. Time spending in nest building behaviour varied significantly at different days (CK: $\chi^{2}=4.5$, df $=4, p<0.05$; WTK: $\chi^{2}=21.1$, df $\left.=5, \mathrm{p}<0.001\right)$ and at different hours of the day (CK: $\chi^{2}=$ $\left.34.4, \mathrm{df}=11, \mathrm{p}<0.001 ; \mathrm{WTK}: \chi^{2}=80.2, \mathrm{df}=5, \mathrm{p}<0.001\right)$

Kingfishers were very much conscious about their security of building nest. They rejected three completed nests (one of white-throated kingfisher in CUC and two of common kingfisher in Savar) and looked for other places to build the nest whenever the researchers and/or somebody else were following them. They left the nest building for other reasons also. For instance, one pair of whitethroated kingfisher rejected the nest after $10^{\text {th }}$ day of nest building possibly because there was a root of a mango tree in parallel position of the nest, which may be obstructed their easy movement. Then they selected an abandoned old nest at the nearby suitable site and reconstructed the nest and laid eggs. The common kingfisher also rejected/left two nests (one at Nikunjo and another one at Savar) probably for the inconvenience of soil conditions. The time spent in nest building increased as the nest building period proceeded and the percentage of time spent was significantly correlated with the days of nest building (CK: $\mathrm{r}=0.980, \mathrm{df}=11, \mathrm{p}<0.001$; WTK: $\mathrm{r}=0.979$, $\mathrm{df}=4, \mathrm{p}<0.001$ ).

The common kingfisher did not build nest in association with the nest of same or other species and only one nest was found in each nesting site. On the other hand, white-throated kingfisher built nests in association with the nest of other species in $14.3 \%$ cases and in $85.7 \%$ cases without association. In CUC, white-throated kingfisher built nests in association with the nests of Jungle Myna (Acridotheres fuscus), Plain Martin (Riparia paludicola) and Blue-tailed Bee-eater (Merops philippinus) in 2009. But in 2010, two nests were found without any association in CUC. In Savar and BNMC, only one nest was built in each territory and no other nests of other birds were seen associated.

The surrounding macro and micro-habitats such as agricultural lands ( $\mathrm{n}=$ 9), groves $(n=7)$, perching sites (tree, $n=7)$ and electric lines $(n=8)$ and human habitations $(\mathrm{n}=9)$ were found to be closer to the nest sites (Table 2). The 
distance of surrounding macro and micro-habitats of both species varied significantly (CK: $\chi^{2}=43.9$, df $=4, p<0.001$; WTK: $\chi^{2}=126.1$, df $=4, p<0.001$ ).

The agricultural lands and groves provided a variety of protein rich insects and other prey for the growing nestlings as well as for the parents. It supports the findings of Ali et al. (2010). The nearest small trees, shrubs, sticks and electric lines served as a perching site for overseeing the nest and searching for prey. This observation also agrees with the findings of Asokan et al. (2010).

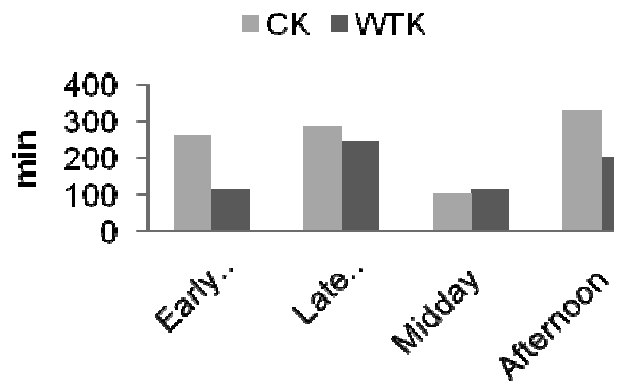

Fig. 2. Nest building behaviour at different day periods. $(\mathrm{CK}=$ Common kingfisher and WTK $=$ White-throated kingfisher $)$

$\square C K=W T K$

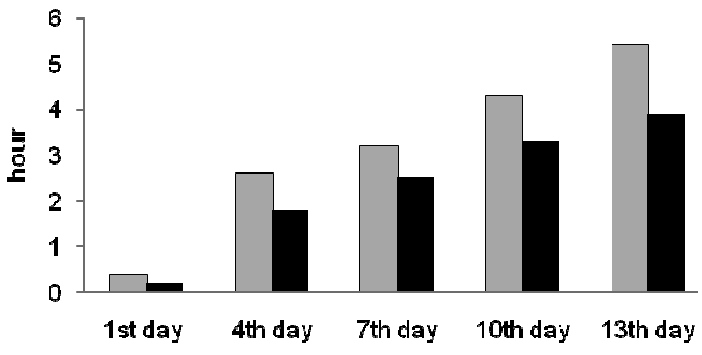

Fig. 3. Time spent in nest building (in hour) at different day. $(\mathrm{CK}=$ Common kingfisher and WTK $=$ White-throated kingfisher).

The nest tunnel is gradually narrow from the entrance; distal part slightly upward and straight. Ali and Ripley (1987) reported that it is a horizontal tunnel. The tunnel ended in a widened egg chamber. More or less similar findings were reported by others for both species (Whistler 1986, Ali and Ripley 1987, Arkive 2015 a,b, Naturia 2014 a,b, Wikipedia 2015 b,c). The depth of the tunnel of different species was higher in other countries than this study (Ali et al. 2010, Ali and Ripley 1987, Heneberg 2004, Wikipedia 2015 a,b). The Common Kingfisher did not build any false nest but White-throated Kingfisher built several false nests (mean $58.1 \% \pm 40.3, \mathrm{n}=10$ ) in both sides of the true nest ( $1-5$ on each side). The number of false nests was more at the left side $(57.1 \%)$ than the right side of the true nest. 
The measurement of the true nests of both kingfishers may be described under the following sub-heads, such as:

The length of nest tunnel (nest depth) of white-throated kingfisher (44- 86 $\mathrm{cm}$ long, median $59.25 \mathrm{~cm}, \mathrm{n}=10$ ) was more or less double of the common kingfisher (31- $48 \mathrm{~cm}$ long, median $36.5 \mathrm{~cm}, \mathrm{n}=8$ ).

Table 2. Habitat around the nests

\begin{tabular}{lcccccc}
\hline \multicolumn{1}{c}{ Variables } & \multicolumn{2}{c}{ Mean \pm Sd $(\mathrm{m})$} & \multicolumn{2}{c}{ Mini. $(\mathrm{m})$} & \multicolumn{2}{c}{ Maxi. $(\mathrm{m})$} \\
\hline Distance to the nearest $(\mathrm{m})$ & ${ }^{*} \mathrm{CK}(\mathrm{n}=9)$ & ${ }^{*}$ WTK $(\mathrm{N}=10)$ & $\mathrm{CK}$ & WTK & CK & WTK \\
\hline Agricultural lands & $36.7 \pm 20.1$ & $59.97 \pm 48.3$ & 3.04 & 6.7 & 64 & 137.1 \\
Groves & $4.4 \pm 3.1$ & $24.2 \pm 14.5$ & 0.9 & 9.1 & 5.2 & 47.5 \\
Tree & $10.4 \pm 9.05$ & $2.9 \pm 1.5$ & 0.6 & 0.9 & 24.3 & 5.1 \\
Electric line & $20.7 \pm 4.6$ & $12.3 \pm 3.7$ & 14 & 7.6 & 27.43 & 18.28 \\
Human habitation & $40.1 \pm 14.6$ & $82.7 \pm 60.2$ & 18 & 9.14 & 57.9 & 170.7 \\
\hline
\end{tabular}

${ }^{*} \mathrm{CK}=$ Common and WTK $=$ White-throated kingfisher .

The horizontal diameter of the outer opening of the hole of white-throated kingfisher was almost double $(6.5-14 \mathrm{~cm}$, median $9.5 \mathrm{~cm}, \mathrm{n}=10)$ than the common kingfisher (3.8 to $5 \mathrm{~cm}$, median $4.25, \mathrm{n}=8$ ) whereas the vertical diameter was almost same for both species (CK: $7.7-10 \mathrm{~cm}$, median $4.25 \mathrm{~cm}, \mathrm{n}$ = 8; WTK: 7.5 to $12 \mathrm{~cm}$, median $10.5 \mathrm{~cm}, \mathrm{n}=10$ ). These two measurements were 5.0 to $9.5 \mathrm{~cm}$ and 4.5 to $9.0 \mathrm{~cm}$, respectively for common kingfisher (Heneberg 2004) and the diameter of the entrance of the nest tunnel ranged from 6.0 to 9.1 cm (Whistler 1986, Ali and Ripley 1987). But for white-throated kingfisher the diameter was more or less same to those reported by other workers (Ali and Ripley 1987, Maduramozhi 2008, Ali et al. 2010).

The egg chamber is oval-shape in both species (Whistler 1986, Arkive 2015a,b).

The horizontal diameter of the egg chamber was 11 to $15 \mathrm{~cm}$ (median 12.7 $\mathrm{cm}, \mathrm{n}=8$ ) for common kingfisher and 11 to $21 \mathrm{~cm}$ (median $17 \mathrm{~cm}, \mathrm{n}=10$ ) for white-throated kingfisher, whereas the vertical diameters of both species were almost same (CK : $11-13 \mathrm{~cm}$, median $11.6 \mathrm{~cm}, \mathrm{n}=8$; WTK: $10-16 \mathrm{~cm}$, median $12 \mathrm{~cm}, \mathrm{n}=10$ ). These were more or less same in comparison to other areas as found by different workers (Whistler 1986, Ali and Ripley 1987).

The nesting height of common kingfisher was almost double $(55-82 \mathrm{~cm}$, median $100.5 \mathrm{~cm}, \mathrm{n}=8)$ than the white-throated kingfisher $(33-132 \mathrm{~cm}$, median $60.5 \mathrm{~cm}, \mathrm{n}=10$ ) for from the ground base whereas below from the upper ground level of the nesting hills was one-third less from white-throated kingfisher (CK: $85-110 \mathrm{~cm}$, median $69 \mathrm{~cm}, \mathrm{n}=8$; WTK: $31-466 \mathrm{~cm}$, median $81 \mathrm{~cm}, \mathrm{n}=8$ ).

None of the kingfishers used any nesting material. Such observation was also reported for common kingfisher (Heneberg 2004). The chamber and passage 
contained fish parts (small scale, tail or fin) and faeces of the birds. The chamber and passage of common kingfisher always contained minute fish bones disgorged by the birds (Whistler 1986); the nest is so slimy and smelly and full of fish scales that the adult emerging from the entrance often takes a bath in the stream before flying off in search for food (Flegg 1984). The bird laid eggs on the loose soil of the earthen floor of the chamber. Similar findings were also reported by other workers (Whistler 1986, Wikipedia 2015 a, Arkive 2015 a,b).

Both species reused old nests through cleaning. The White-throated Kingfisher used $50 \%$ old nests whereas common kingfisher used $37.5 \%$. It is evident that if these species do not feel disturbance in one year, they reused those nests next year. During this study period, the nests, those were closely observed and frequently entered the nesting territories for the measurements of eggs and/or nestlings, they avoided those nesting sites next year.

Common kingfisher took comparatively longer time, 12 - 20 days (mean 16.1 \pm 2.5 days, $n=8$ ) for building nest than that of white-throated kingfisher, $8-18$ days (mean $13.2 \pm 3.5$ days, $\mathrm{n}=10$ ). The nest building did not vary significantly in both species (CK: $\chi^{2}=0.8, \mathrm{df}=7, \mathrm{p}>0.05$; WTK: $\chi^{2}=1.2, \mathrm{df}=9, \mathrm{p}>0.05$ )

Common kingfisher spent more time (16 - 20 days, $\mathrm{n}=3)$ than whitethroated kingfisher (15 - 18 days, $\mathrm{n}=5$ ) for building new nest. On the other hand, they spent comparatively less time in rebuilding/renovating old nest (CK: 12 - 15 days, $n=3$; WTK: $8-13$ days, $n=5$ ).

\section{CONCLUSION}

The common kingfisher and white-throated kingfisher prefer abandoned, isolated and nearly $90^{\circ}$ sloppy vertical sites for nest building. Both the partners of both species take part in nest building. The common kingfishers do not built any false nest but the white-throated kingfishers build a several number of false nests on both sides of the true nests. Both the kingfishers do not use any nesting material. Both the species reused the abandoned nest after cleaning. The common kingfishers take more time than white-throated kingfishers in building both new and old nests. The building of a new nest takes more time than renovating the old one.

Acknowledgements: The authors are grateful to the Ministry of Science, Information and Communication Technology for funding the research. They express their gratitude to Mr. Tauhid Uddin Ahmed, Ex-Principal Scientific Officer, IECDR, Mohakhali, Dhaka, Bangladesh for making helpful and constructive comments to enrich this manuscript. 


\section{LITERATURE CITED}

ALI, A.M.S., ASOKAN S. and MANIKANNAN, R. 2010. Observations on nesting ecology of whitebreasted kingfisher Halcyon smyrnensis (Aves: Coraciiformes) in Cauvery Delta, Tamil Nadu, Southern India. J. of Ecol. and the Nat. Environ. 2(7): 134-139.

ALI, S. 1979. The Book of Indian Birds, Second edition.Bombay Natural History Society. Oxford University Press, Bombay, Delhi, Calcatta, Madras. xlii +737 pp.

ALI, S. and RIPLEY, S.D. 1987. Compact Handbook of the Birds of India and Pakistan. Oxford University Press, New York. xlvii + 187 pp.

ALTMANN, J. 1974. Observational study of behaviour: Sampling methods. Behav. 49: 227- 267.

ARKIVE. 2015a. Available at http://www.arkive.org/kingfisher/alcedo-atthis/info.html. Accessed date: 10-07-15.

ARKIVE. 2015b. Available at http://www.arkive.org/kingfisher/Halcyon-smyrnensis /info.html. Accessed date: 10-07-15.

ASOKAN, S., ALI, A.M.S. and MANIKANNAN, R. 2010. Breeding biology of the small bee-eater Merops orientalis (Latham, 1801) in Nagapattinam District, Tamil Nadu, India. J. Threat. Taxa. 2(4): 797-804.

AVIAN WEB. 2015. Available at http://www.avianweb.com/ whitethroatedkingfishers. html. Accessed date: 07-6-2015.

BALASUBRAMANIAN, P. 1992. New nesting site of the Indian white-breasted kingfisher Halcyon smyrnensis fusca (Boddaert). J. Bombay Nat. Hist. Soc. 89: 124.

BROOKS, R.P. and DAVIS, W.J. 1987. Habitat selection by breeding belted kingfishers (Ceryle alcyon). Amer. Mid. Nat. 117: 63-70.

CAMPOS, F., FERNANDEZ, A., GUTIERREZ-CORCHERO, F., MARTIN-SANTOS, F. and SANTOS, P. 2000. Diet of the Eurasian kingfisher (Alcedo atthis) in northern Spain. J. Folia Zool. 49: 115-121.

FLEGG, J. 1984. Discovering Birds. The Hamlyn Publishing Group Limited, London. pp. 176.

HENEBERG, P. 2004. Soil particle composition of Eurasian Kingfishers' (Alcedo atthis) nest sites. Acta Zool. Acad. Sci. Hunga. 50: 185-193.

HOOGLAND, J.L. and SHERMAN, P.W. 1976. Advantages and disadvantages of bank swallow (Riparia riparia) coloniality. Ecol. Monogr. 46: 33-58.

IRIBARREN, I.B. and NEVADO, L.D. 1982. Contrubution l'etude du régime alimentaire du MartinPecheur (Alcedo atthis L. 1758). Alauda 50: 81-91.

IUCN, BANGLADESH. 2000. Red Book of Threatened Birds of Bangladesh. IUCN-The World Conservation Union. xii +116 pp.

JERDON, T.C. 1982. The Birds of India. The Military orphan press, Calcatta. xlv+535 pp.

LACK, D. 1968: Ecological Adaptations for Breeding in Birds. Methuen, London. 409 pp.

LI and MARTIN, T.E. 1991. Nest site selection and nesting success of cavity-nesting birds in high elevation forest drainages. Auk. 108: 405-418.

MADHURAMOZHI, G. 2008. Ecology of the white-breasted kingfisher, Halcyon smyrnensis (Linnaeus, 1758) with special reference to its population, foraging and breeding in Nagapattinam, Tamil Nadu, India. Ph.D. Thesis. Bharathidasan University, Tiruchirappalli, India.

MARTIN, T.E. and ROPER, J.J. 1988. Nest predation and nest-site selection of a western population of the hermit thrush. Condor 90: 51-57. 
MORGAN, R. and GLUE, D. 1977. Breeding, mortality and movements of kingfishers. Bird Study 24: $15-24$.

NATURIA, 2014a. Available at http://www.naturia.per.sg/buloh/birds/Alcedo_atthis.htm. Accessed date: $10-09-2014$.

NATURIA. 2014b. Available at http://www.naturia.per.sg/buloh/birds/Halcyon_smyrnensis. htm. Accessed date: 10-09-2014.

PALKER, S.B., LOVALEKAR, R.J. and JOSHI, V.V. 2009. Breeding biology of white-breasted kingfisher, Halcyon smyrnensis. Indian Birds. 4: 104-105.

PERIS, S.J. and RODRIGUEZ, R. 1996. Some factors related to distribution by breeding kingfisher (Alcedo atthis). Ekol. Pol. 44: 31-38.

PERIS, S.J. and RODRIGUEZ, R. 1997. A survey of the Eurasian kingfisher (Alcedo atthis) and its relationship with watercourses quality. Folia Zool. 46: 33-42.

RAVEN, P. 1986. The size of minnow prey in the diet of young Kingfishers, Alcedo atthis. Bird Study 33: $6-11$.

SIDDIQUI, K.U., ISLAM, M.A., KABIR, S.M.H., AHMAD, M., AHMED, A.T.A., RAHMAN, A.K.M., HAQUE, E.U., AHMED, Z.U., BEGUM, Z.N.T., HASSAN, M.A., KHONDKER, M. and RAHMAN, M.M. (Eds.). 2008. Encyclopedia of Flora and Fauna of Bangladesh. Vol. 26. Birds. Asiatic Society of Bangladesh, Dhaka: xL + 662 pp.

WHISTLER, H. 1986. Handbook of Indian Birds. Cosmo Publications, New Delhi. pp. xxiv +438 .

WHITE, F.N., BARTHOLOMEW, G.A. and KINNEY, J.L. 1978. Physiological and ecological correlates of tunnel nesting in the European bee-eater, Merops apiaster. Physiol. Zool. 51: 140-154.

WIKIPEDIA. 2015a. Available at http://en.wikipedia.org/wiki/ Kingfisher. Accessed date 15-062015.

WIKIPEDIA. 2015b. Available at http://en.wikipedia.org/wiki/Common_Kingfisher. Accessed date 15-06-2015.

WIKIPEDIA. 2015c. Available at http://en.wikipedia.org/wiki/White-throated_Kingfisher. Accessed date $15-06-2015$. 